\title{
RANCANG BANGUN SISTEM INFORMASI MANAJEMEN SKRIPSI PROGRAM STUDI TEKNIK INFORMATIKA MENGGUNAKAN METODE FAST
}

\author{
Galang Rizka Maulana', Hendra Pradibta ${ }^{2}$, Ekojono $^{3}$ \\ ${ }^{1}$ Program Studi Teknik Informatika, ${ }^{2,3}$ Jurusan Teknik Elektro, Politeknik Negeri Malang \\ galang0806@gmail.com, ${ }^{2}$ ndropradibta@yahoo.com, ${ }^{3}$ ekojono2000@yahoo.com
}

\begin{abstract}
Abstrak
Skripsi merupakan tahap akhir yang harus ditempuh oleh mahasiswa di Politeknik Negeri Malang dalam hal ini Program Studi Teknik Informatika. Pada tahap ini mahasiswa diharuskan membangun laporan skripsi berdasarkan disiplin ilmu yang sudah didapatkan selama proses perkuliahan di kampus. Banyak metode yang digunakan dalam pengembangan perangkat lunak. Salah satu di antaranya adalah metode FAST (Framework for the Application of System Technique). Metode FAST adalah metode pengembangan aplikasi yang menggabungkan beberapa teknik pengembangan aplikasi lainnya. Penggunaan metode FAST untuk membangun aplikasi berdasarkan analisa kerangka berpikir PIECES (Performance, Information, Economy, Control, Efficiency, Service) cocok digunakan karena metode ini dapat memahami dan menganalisa kebutuhan user. Penggunaan metode FAST dalam perancangan dan pembangunan aplikasi ini tepat berdasarkan hasil dari perbandingan dengan metode waterfall, pengujian fungsional dan survei terhadap user. Hasil dari perbandingan dengan metode waterfall menunjukkan bahwa pengembangan aplikasi menggunakan metode FAST lebih lama 5 hari tetapi memiliki kelebihan modul yang bersifat dinamis. Hasil dari pengujian fungsional menunjukkan bahwa aplikasi ini sudah berjalan dengan baik sedangkan berdasarkan hasil pengujian kegunaan, menurut 5\% user aplikasi ini sangat mudah digunakan, sedangkan 85\% user aplikasi ini mudah digunakan dan 10\% user mengatakan bahwa aplikasi ini sulit digunakan.
\end{abstract}

Kata kunci: Sistem Informasi Manajemen Skripsi, FAST, PIECES

\section{Pendahuluan}

Skripsi merupakan tahap akhir yang harus ditempuh oleh mahasiswa di Politeknik Negeri Malang dalam hal ini Program Studi Teknik Informatika. Pada tahap ini mahasiswa diharuskan membangun laporan skripsi berdasarkan disiplin ilmu yang sudah didapatkan selama proses perkuliahan di kampus. Terdapat beberapa tahapan dalam skripsi yaitu pengajuan proposal skripsi, seminar skripsi, revisi proposal skripsi, pemilihan pembimbing skripsi, seminar hasil, seminar skripsi dan revisi.

Panitia mengalami kesulitan dengan banyaknya dokumen skripsi untuk diarsipkan. Hilang atau terselipnya dokumen skripsi yang tentunya akan merugikan mahasiswa maupun panitia skripsi. Oleh karena itu, diperlukan aplikasi yang mampu mengelola pelaksanaan skripsi sekaligus pengarsipan secara online serta penyampaian informasi yang efektif.

Menurut Whitten (2004), FAST (Framework for the Application of System Technique) adalah sebuah metode untuk membangun aplikasi yang merupakan integrasi dari beberapa metode untuk membangun aplikasi. Penggunaan metode FAST sudah cukup banyak digunakan dan menghasilkan aplikasi yang sesuai dengan kebutuhan pengguna.
Pada penelitian yang dilakukan oleh Sufriana (2010), penggunaan metode FAST pada Rancang Bangun Sistem Informasi Pengelolaan Keuangan Daerah (Studi Kasus Pada Skpd Dinas Energi Dan Sumber Daya Mineral Kabupaten Kepulauan Sangihe) mneghasilkan sistem yang mempermudah dan mempercepat proses pengelolaan daerah sehingga menghasilkan informasi yang akurat, relevan dan tepat waktu guna pengambilan keputusan terutama kontrol penggunaan anggaran, pencatatan transaksi serta evaluasi dan perkiraan anggaran ditahun yang akan datang.

Sedangkan pada penelitian yang dilakukan oleh Rosyadi (2012) dengan judul Analisa Dan Perancangan Sistem Informasi Persediaan Barang Dengan Menggunakan Metode FAST Pada CV. Tri Jaya, menghasilkan sistem informasi persediaan barang yang dibangun sesuai dengan perancangan sistem dan telah sesuai dengan kebutuhan pengguna sebagaimana telah didefinisikan berdasarkan metode FAST (Framework for the Application of System Technique).

Metode ini cocok digunakan untuk merancang aplikasi manajemen skripsi karena metode ini menyediakan mekanisme untuk memahami dan menganalisis kebutuhan pengguna, pemilihan solusi yang layak, hingga pembuatan sistem yang lebih 
terorganisir. Dengan adanya aplikasi ini, dapat mempermudah panitia dalam melakukan pengelolaan skripsi dan mempermudah mahasiswa dalam menerima informasi.

\section{Metode}

\subsection{Metode Penelitian}

Berikut merupakan kerangka penelitian yang digunakan oleh penulis:

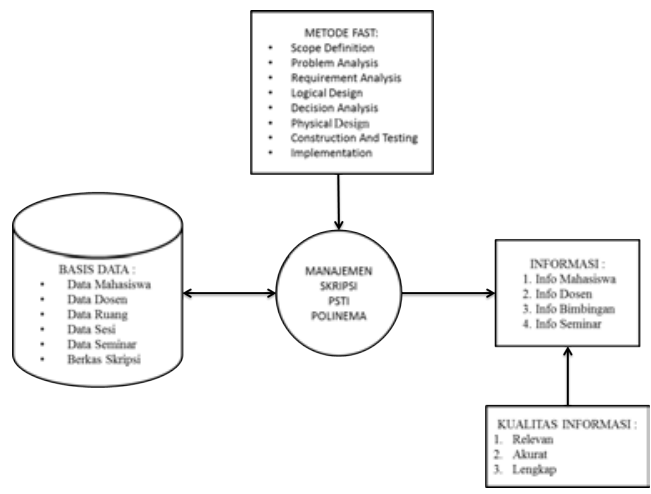

Gambar 2.1 Kerangka Konsep Penelitian

Sedangkan perancangan aplikasi ini menggunakan metode FAST (Framework for the Application of System Technique) dan dibagi menjadi menjadi 6 tahap yaitu :

\subsection{Perancangan}

\subsubsection{Scope Definition}

Definisi ruang lingkup merupakan tahap awal yang ada pada FAST. Tahap ini juga merupakan landasan untuk tahapan selanjutnya. Definisi ruang lingkup meliputi : ruang lingkup proyek, struktur organisasi, sumber daya yang terlibat, kerangka pemecahan masalah dengan PIECES (Performancce, Information, Economic, Control, Efficiency, Service). Berikut ini merupakan hasil analisa permasalahan yang ada dengan menggunakan kerangka PIECES:

\begin{tabular}{|c|c|c|}
\hline \multirow{4}{*}{$\mathbf{P}$} & \multicolumn{3}{|c|}{ P (Performance) } \\
& $\begin{array}{l}\text { 1. Belum adanya sistem informasi } \\
\text { yang mengelola pelaksanaan } \\
\text { skripsi. }\end{array}$ \\
\hline I & $\begin{array}{l}\text { 1. Kurangnya informasi mengenai } \\
\text { pelaksanaan skripsi. } \\
\text { Data belum terorganisir secara baik. }\end{array}$ \\
\hline
\end{tabular}

\begin{tabular}{|c|c|}
\hline \multirow[b]{2}{*}{$\mathbf{E}$} & $\mathrm{E}$ (Economy) \\
\hline & $\begin{array}{l}\text { 1. Penggunaan kertas yang cukup } \\
\text { banyak ketika ada berkas yang } \\
\text { terselip atau hilang. }\end{array}$ \\
\hline \multirow[b]{2}{*}{ C } & $\mathrm{C}$ (Control) \\
\hline & $\begin{array}{l}\text { 1. Pengendalian terhadap proses } \\
\text { pelaksanaan skripsi terumata dalam } \\
\text { hal pengarsipan berkas. }\end{array}$ \\
\hline \multirow[b]{2}{*}{$\mathbf{E}$} & $\mathrm{E}$ (Efficiency) \\
\hline & $\begin{array}{l}\text { 1. Membutuhkan waktu yang lama } \\
\text { dari mahasiswa ke panitia untuk } \\
\text { pengarsipan berkas. }\end{array}$ \\
\hline & S (Service) \\
\hline $\mathbf{S}$ & $\begin{array}{l}\text { 1. Belum adanya sistem informasi } \\
\text { untuk pengelolaan skripsi. } \\
\text { 2. Belum adanya sistem informasi } \\
\text { untuk menyampaikan pelaksanaan } \\
\text { skripsi. }\end{array}$ \\
\hline
\end{tabular}

Tabel 2.1 Kerangka PIECES

\subsubsection{Problem Analysis}

Pada tahap analisa masalah, dilakukan proses analisa masalah apa saja yang muncul pada sistem yang ada saat ini. Dari hasil analisa tersebut didapat sebuah laporan yang menerangkan mengenai problem, cause, effect, dan solution benefit.

\subsubsection{Requirement Analysis}

Kebutuhan yang dibutuhkan untuk membangun dan mengimplementasikan aplikasi ini adalah software yang memiliki penggunaan yang mudah dari sisi panitia, dosen dan mahasiswa.

\subsubsection{Logical Design}

Pada tahap logical design dilakukan proses transformasi dari kebutuhan bisnis yang telah didefiniskan di fase requirement analysis ke dalam model sistem yang nantinya akan dibangun, dimana didalamnya menyangkut penggunaan teknologi data, proses, dan antarmuka. Logical Design meliputi :

\section{- Logical Data Model}

Logical Data Model merupakan penjabaran dari data yang digunakan dan digambarkan berupa Entity Relationship Diagram berikut : 


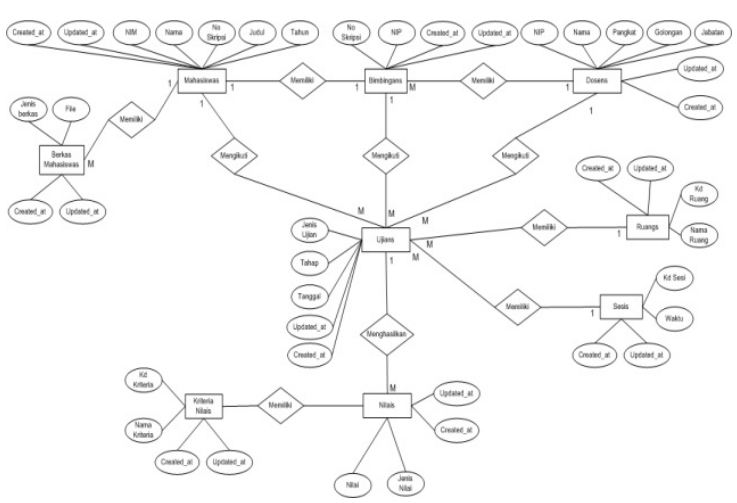

Gambar 2.2 Entity Relationship Diagram

- Logical Process Model

Logical Process Model merupakan proses bisnis pelaksanaan skripsi sesuai dengan flowchart berikut :

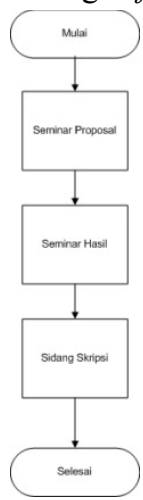

Gambar 2.2 Flowchart

\section{- $\quad$ Logical Interface Design}

Logical Interface Design dibagi menjadi 2 yaitu

\section{Login Page}

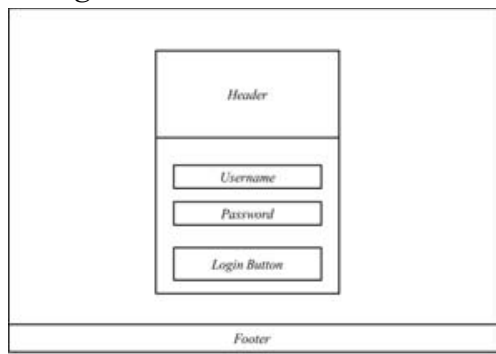

Gambar 2.3 Rancangan Login Page

User Page

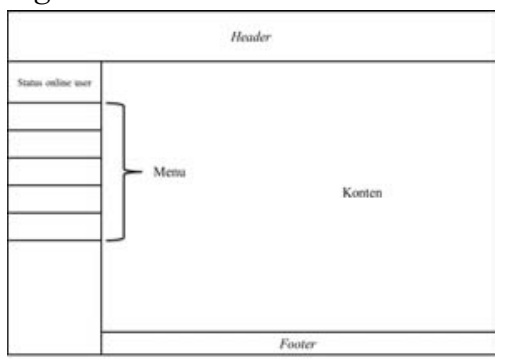

Gambar 2.4 Rancangan User Page

\subsubsection{Decision Analysis}

Pada tahap analisa keputusan, ada beberapa hal yang dilakukan antara lain : Identifikasi kandidat dari solusi teknis, Analisa kandidat solusi yang ada untuk berbagai kemungkinan, Rekomendasi beberapa kandidat dari perangkat lunak dan perangkat keras yang nantinya dipakai untuk implementasi sistem.

Berdasarkan hasil dari requirement analysis maka, terdapat dua kandidat untuk kebutuhan software yaitu :

\begin{tabular}{|c|c|c|c|}
\hline Kriteria & Bobot & $\begin{array}{c}\text { Kandidat } \\
1\end{array}$ & $\begin{array}{c}\text { Kandidat } \\
2\end{array}$ \\
\hline Operasional & $30 \%$ & 100 & 100 \\
\hline Teknis & $30 \%$ & 70 & 90 \\
\hline Kontrol & $30 \%$ & 100 & 100 \\
\hline Efisiensi & $10 \%$ & 70 & 95 \\
\hline Total & $100 \%$ & 85 & 96.25 \\
\hline
\end{tabular}

Tabel 3.1 Analisa kelayakan software

\subsubsection{Physical Design}

\section{Use Case Diagram}

Berikut merupakan use case diagram untuk aplikasi manajemen skripsi :

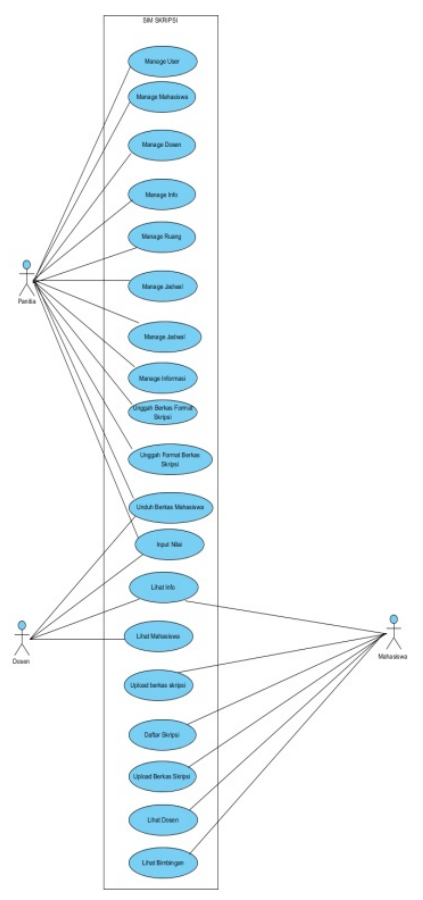

Gambar 2.5 Use Case Diagram 


\section{Object Relation Modelling Diagram}

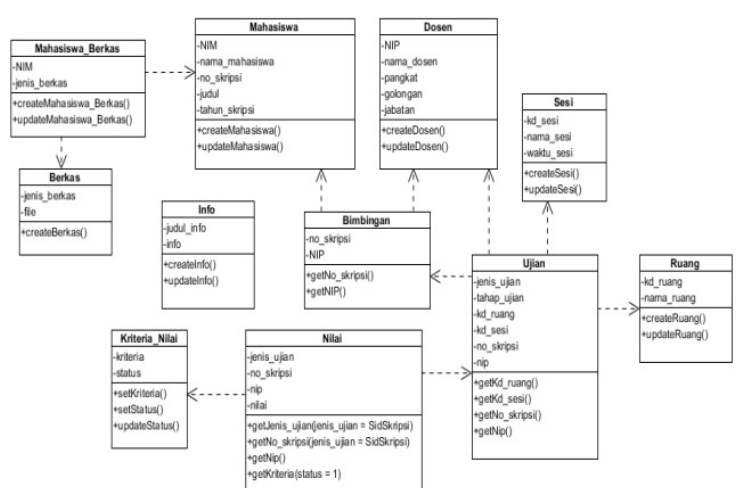

Gambar 2.6 Object Relation Modelling Diagram

\section{Mapping Database}

Berikut merupakan mapping database untuk aplikasi manajemen skripsi :

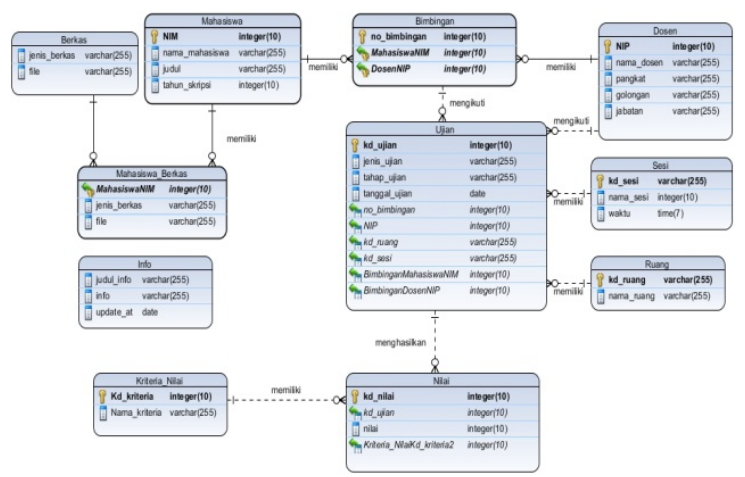

Gambar 2.7 Mapping Database

3. Hasil

Aplikasi yang dihasilkan sudah mengatasi berbagai permasalahan sesuai dengan kerangka PIECES. Aplikasi ini memiliki 3 jenis user yaitu panitia, mahasiswa dan dosen. Tiap jenis user memiliki hak akses yang berbeda-beda. Berikut merupakan beberapa tampilan aplikasi yang telah selesai dibuat:

\subsection{Login Page}

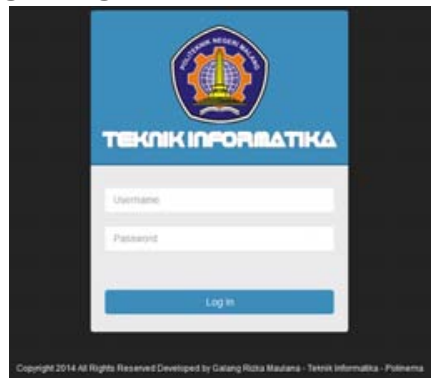

Gambar 3.1 Tampilan Login Page

\subsection{User Page}

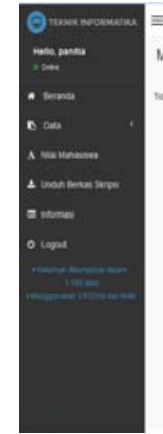

Gambar 3.2 Tampilan User Page-panitia
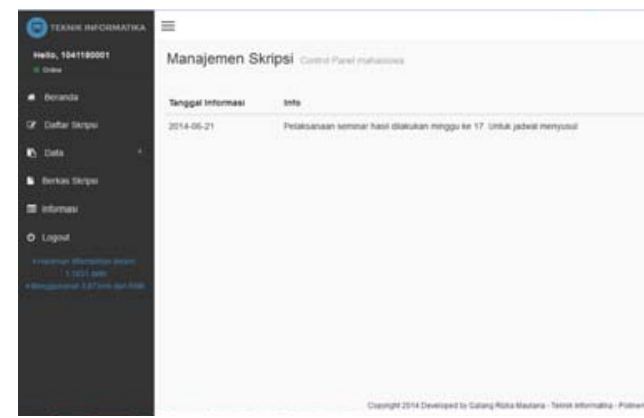

Gambar 3.3 Tampilan User Page-mahasiswa

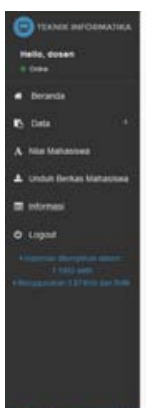

Gambar 3.4 Tampilan User Page-dosen

\section{Pembahasan}

\subsection{Analisa Pengujian Fungsional}

Pada pengujian fungsional dilakukan dengan cara memberikan kondisi pada 13 modul utama dalam sistem lalu membandingkan antara hasil yang diharapkan dan hasil pengujian serta menentukan bagian dari kerangka PIECES yang digunakan.

Berdasarkan hasil pengujian fungsional, sistem sudah berjalan sesuai dengan hasil yang diharapkan berdasarkan kerangka PIECES.

\subsection{Perbandingan Metode}

Untuk mengetahui kinerja metode pengembangan yang digunakan untuk membangun SIM Skripsi, dilakukan perbandingan kinerja antara metode pengembangan Waterfall yang digunakan untuk membangun SI-LA dengan metode FAST pada SIM Skripsi. 


\subsection{Analisa Pengujian Kegunaan}

Pengujian kegunaan dilakukan dengan melakukan uji coba kepada panitia dan mahasiswa untuk mengukur tingkat kemudahan operasional aplikasi dan kepuasan pengguna.

Hasil dari pengujian kegunaan untuk operasional adalah :

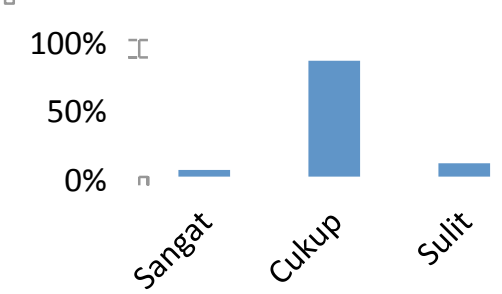

Berdasarkan hasil wawancara pengujian kegunaan untuk operasional yang telah dilakukan, menurut 5\% dari pengguna aplikasi ini sangat mudah digunakan, $85 \%$ dari pengguna aplikasi ini mudah digunakan sedangkan menurut $10 \%$ dari pengguna aplikasi ini cukup mudah digunakan karena masih terbiasa menggunakan cara konvensional.

\section{Penutup}

\subsection{Simpulan}

Berdasarkan hasil penelitian yang telah dilakukan, maka dapat ditarik kesimpulan sebagai berikut :

1. Aplikasi Manajemen Pelaksanaan Skripsi Pada Program Studi Teknik Informatika Politeknik Negeri Malang yang dibangun sesuai dengan perancangan sistem dan telah sesuai dengan kebutuhan pengguna sebagaimana telah didefinisikan berdasarkan metode FAST (Framework for the Application of System Technique).

2. Aplikasi Manajemen Pelaksanaan Skripsi Pada Program Studi Teknik Informatika Politeknik Negeri Malang yang dibangun sudah mengatasi permasalahan yang ada berdasarkan kerangka PIECES (Performance, Information, Economics, Control, Efficiency, Service).

3. Pada pengujian fungsional semua fungsi telah berjalan dengan baik dengan hasil yang didapat yaitu semua fungsi valid dan sesuai dengan proses bisnis yang telah dideskripsikan.

4. Pada hasil pengujian kegunaan operasional Aplikasi Manajemen Pelaksanaan Skripsi Pada Program Studi Teknik Informatika Politeknik Negeri Malang memudahkan panitia untuk mengelola pelaksanaan skripsi.

\subsection{Saran}

Adapun saran-saran dari penulis yang dapat dijadikan bahan pertimbangan untuk pengembangan aplikasi ini antara lain:

1. Otomasi jadwal seminar agar lebih mempermudah panitia dalam penjadwalan.

\section{Daftar Pustaka:}

Rosyadi, Ivan Januar., Rachmadi, Aditya., Priharsari, Diah (2012): Analisa Dan Perancangan Sistem Informasi Persediaan Barang Dengan Menggunakan Metode FAST Pada CV. Tri Jaya. PTIIK Universitas Brawijaya.

Sufriana, Heri., Tjahyanto, Aris (2010): Analisa Dan Desain Sistem Informasi Aktiva Tetap Dan Persediaan Pada PDAM Kabupaten Magetan, Surabaya: Makalah Seminar Nasional ITS.

Whitten, Jeffery L., Bentley, Lonnie D., Dittman, Kevin C. (2004): System Analysis and Design Method 7th edition. New York: McGrawHill Education. 